\title{
Wanneer gaan daardie dag kom ...?
}

\begin{tabular}{|c|c|}
\hline \multicolumn{2}{|l|}{$\begin{array}{l}\text { Book Title: } \\
\text { Ware mense } \\
\text { Book Cover: }\end{array}$} \\
\hline ware & tense \\
\hline $\begin{array}{l}\text { Author: } \\
\text { Bart de Graaff }\end{array}$ & \\
\hline $\begin{array}{l}\text { ISBN: } \\
978-1-4853-0\end{array}$ & $80-8$ \\
\hline $\begin{array}{l}\text { Publisher: } \\
\text { Protea Boekhu } \\
\text { *Book price a }\end{array}$ & $\begin{array}{l}\text { S, 2017, R250* } \\
\text { time of review }\end{array}$ \\
\hline $\begin{array}{l}\text { Review Title: } \\
\text { Wanneer gaar } \\
\text { kom ...? }\end{array}$ & daardie dag \\
\hline $\begin{array}{l}\text { Reviewer: } \\
\text { Christo van Re }\end{array}$ & nsburg ${ }^{1} \dagger$ \\
\hline $\begin{array}{l}\text { Affiliation: } \\
{ }^{1} \text { Research Uni } \\
\text { and Literature } \\
\text { Context, Nort } \\
\text { University, So }\end{array}$ & $\begin{array}{l}\text { Languages } \\
\text { in the SA } \\
\text {-West } \\
\text { th Africa }\end{array}$ \\
\hline $\begin{array}{l}\text { Correspondin } \\
\text { Christo van Re } \\
\text { cvrensb@mw }\end{array}$ & $\begin{array}{l}\text { author: } \\
\text { nsburg, } \\
\text { b.co.za }\end{array}$ \\
\hline $\begin{array}{l}\text { How to cite th } \\
\text { Van Rensburg } \\
\text { 'Wanneer gaa } \\
\text { kom ...?', Liter } \\
\text { a1533. https:/ } \\
\text { org/10.4102/l }\end{array}$ & $\begin{array}{l}\text { s book review: } \\
\text { C., } 2018 \text {, } \\
\text { daardie dag } \\
\text { tor } 39(1) \text {, } \\
\text { /doi. } \\
\text { t.v39i1.1533 }\end{array}$ \\
\hline $\begin{array}{l}\text { Copyright: } \\
\text { (C) 2018. The A } \\
\text { AOSIS. This wo } \\
\text { under the Crea } \\
\text { Attribution Lice }\end{array}$ & $\begin{array}{l}\text { thors. Licensee: } \\
\text { k is licensed } \\
\text { ive Commons } \\
\text { nse. }\end{array}$ \\
\hline Read online: & \\
\hline 口ifit & $\begin{array}{l}\text { Scan this QR } \\
\text { code with your } \\
\text { smart phone or } \\
\text { mobile device } \\
\text { to read online. }\end{array}$ \\
\hline
\end{tabular}

Die Nederlandse taalhistorikus Bart de Graaff het in 2015 en 2016 met twee besoeke aan SuidAfrika meer probeer uitvind oor die kapteinsfamilies van die Khoi-Khoin waarvan die name 'n paar geslagte gelede beter bekend was as wat dit tans die geval is. Hy het in gesprekke met hulle nasate meermale die versugting gehoor dat hulle geduldig wag op daardie dag wat gaan kom ... die dag wanneer die Khoi-Khoin 'as die oorspronklike bewoners van suidelike Afrika' weer hulle vroeëre posisie gaan herwin (bl. 10). Hulle wens ook al baie lank vir 'vrede, veiligheid en selfs onafhanklikheid' (bl. 66).

Bart de Graaff se boek Ware mense wat hy aan 'alle mense van Khoi-Khoin-afkoms in Suid-Afrika en Namibië' opdra (bl. 158), belig kante van hierdie eerste Afrikaanssprekers se versugtings, hulle lewens en hulle geskiedenisse, en hoe dit met hulle nasate gesteld is. Hy vertel van die kapteins uit eie haard, tóé voormense onder die Khoi-Khoin, die Mense van mense, wat in hierdie vertaling van Daniel Hugo vindingryk Ware mense genoem word. De Graaff verwys na seremoniële verkiesings wat nog steeds gehou word, maar die posbekleërs het eintlik geen mag meer nie, meld hy (bl.69). Miskende identiteit en verontagsaamde menswaardigheid en sóveel grondslenters, vorm deel van hulle verhale. Hulle het mooi name, waarin Khoi-Afrikaans 'n groot rol speel, en wat soms met Nederlands ooreenkom. Dit gebeur dat kaptynsnasate die familienaamgeetradisie van diep uit die vergetelheid nog voortsit, soos in die Adam Kok-familie waar die ou name steeds gehoor word.

Die reputasie van Piet Witvoet, die voorganger van Goliat Yzerbek, leef saam met sy naam voort, kom die leser agter: Hy was die man van talle strooptogte (bl. 14). Goliat Yzerbek se nasate voer in party gevalle hulle van in 'n verhaspelde vorm. Beck was vroeër ook Yzerbek, maar 'n 'blanke amptenaar' het met die inskrywing daarvan kortpad gevat (bl. 19). Die van Bock kom ook voor (bl. 53). Moontlik om dieselfde rede? Goliat Yzerbek het sy naam oorspronklik gekry vanweë sy strydlustige karakter (bl. 15). Stephanus Buffelbout, Hermanus van Wijk, Abraham Swartbooi, Dirk Vilander, Amraal Lamberts, en Jan Bloem, om net'n paar te noem, laat die ou name ook nog voortleef.

Hoe lyk die nasate van die ou kapteinsfamilies vandag? Geert Snoeijer het die skrywer vergesel en vir 'n aantal indrukwekkende portretfoto's gesorg: Dit is Stella Vleermuis dié, sien die leser, en op 'n ander bladsy kyk sy of hy Pauline Yzerbeck reguit in die oë. Elders glimlag miss Rehoboth 2015 skalks. Daar is heelparty foto's, en elkeen voer 'n portretgesprek met die leser. Party van vandag se leiers is ook in die boek afgebeeld. Che Guevera Vleermuis is 'n nasaat van Frederik Flermuis wat die Dorslandtrekkers in 1876 toestemming gegee het om tydelik in die omgewing van Gobabis te vertoef (bl. 119). Sy pa was 'n trotse 'vryheidsvegter' (bl. 115). Hy is tans 'n ITspesialis in Windhoek, maar daar is nie ' $n$ foto van hom geplaas nie. Ook nie van Job Buffel nie. Job het sy ma se inkopies in die apartheidstyd gedra, en gemaak asof hy 'die boy' was, onthou Job met 'n glimlag. Die blankes het op markdae éérste hulle inkopies gedoen, en omdat Job se ma baie lig van kleur was, het sy hierdie geleentheid ook benut (bl. 22).

Synde 'n Nederlander, stoei De Graaff versigtig met die inhoud van Naomi Scholtz se mededeling dat sy 'n 'volbloed Baster' is (bl. 60). Hy kom ook agter wat die betekenis van die Sam Kubisherdenkingsdag is (bl. 69), en wat die kleure van die Basters se vlag beteken (bl. 67). Sy onderskeiding tussen streke wat 'kurkdroog' en 'doodgewoon droog' (bl. 63) is, val op. Hy bevind hom in 'n vreemde 'land van stof en sand. Geregeer deur droogte' (bl. 81). Maar hy weet gou meer van dié land en sy talle inwoners wat Khoi-Khoin-voorsate gehad het; meer as die meeste van die inwoners van Suid-Afrika. Hoekom sou dit die geval wees?

Die boek is vol etimologieë wat die interessantheid daarvan verhoog. Klipfontein het sy naam te danke aan water wat so sterk is dat klippe dit nie kan keer nie (bl. 83), Hardap kom weer van die Khoekhoegowabwoord vir tepel af, na die vorm van 'n koppie in die omgewing,

Note: Die outeur is tydens die voorfinale fase van die redaksionele proses oorlede. Die redaksie het besluit om te volstaan met die teks soos hy dit ingedien het - met die laaste wysigings wat hy self aangebring het. Slegs minimale en noodsaaklike verdere wysigings is deur die redaksie aan die teks aangebring.

$\uparrow, 1938-2018$. 
Aroab beteken 'plek van die blinkblaar-wag-'n-bietjie' (bl. 57), Pokkiesfontein is die plek waar dié siekte Goliat Yzerbeck se vrou geëis het (bl. 106), die Regshande het glo die reg verdedig (bl. 14), en die pleknaam Mier is die variant van Meer wat met verhoogde vokale uitgespreek word (bl. 43).

Mier is vroeër deur 'n Volksraad en 'n President bestuur, en elke burgher het reg op 'n plaas gehad (bl. 45).

In die enkele briewe van Kok, Witvoet en andere wat De Graaff opgeneem het, is Khoi-Afrikaans in die Dokumentnederlands wat hulle probeer skryf het, duidelik sigbaar. Dit blyk uit onder meer die afwesigheid van kongruensie (wij moet), die skryf van kort vokale, byvoorbeeld stan (vir latere staan [bl. 14]), en die skryf van wittig (waar wettig later die norm geword het). Dié verskynsels kom ook voor in ander vroeë voorbeelde van geskrewe Afrikaans in die binneland.

Die voertaal van De Graaff se onderhoude is Afrikaans. Het die segspersone se aptyt vir Khoi heeltemal verdwyn? Een van die nasate van die koninklike Korannafamilie sê 'nee'. Hy beywer hom vir die herlewing van die 'ou, dooie taal van die Korannas, ... die taal brand in hom', sê hy vir De Graaff. Die Khoinaam van Goliat Yzerbeck vertaal hy as 'wit geregtigheid' (bl. 19). Die Korannagemeenskapsraad beywer hulle vandag egter vir jong Korannas wat in Bloemfontein kom werk soek (bl. 23).

De Graaff merk effens sinies op dat die Europese sendingywer eensydig deurgevoer is, en nie op vraag en aanbod gebaseer is nie (bl. 27). Hy verwys na sendelinge wat gedurig uitdagings moes oorkom (Hahn, Wuras), maar tegelykertyd ook na gemeentelede wat heelwat moes verduur wanneer die sendelinge nie net kerstening in die oog gehad het nie. Hulle was ook handelaars (bl. 84) of agente van die heersende politieke bestel (bl. 15), en selfs opstellers van twyfelagtige koopkontrakte (bl. 86). Hulle het plekname ook eensydig verander, soos Klipfontein na Bethanie toe (bl. 84), wat later Brandewijnsfontein geword het (bl. 15). Campbell het Klaarwater se naam na Griekwastad toe verander (bl. 28). Die name van bevolkingsgroepe het hulle veranderingsywer ook nie vrygespring nie, soos die Basters wat deur Campbell se bemoeienis Griekwas geword het (bl. 28) en Schmelen het die !Aman Bethanie-Namas genoem (bl. 84). De Graaff meld dat hulle vandag verbitterd is oor sowel die verlede as die hede (bl. 97).

Dan was daar nog die Korannas, die Afrikaner-Oorlams, die Miermense, die Springbokke en die Regshande. Die laasgenoemde groepe, vertel De Graaff (bl. 25), is in die negentiende eeu deur blankes aangevoer.

Die skrywer is 'n ondersoeker wat noukeurig waargeneem het. Hy gee detailbeskrywings van mense en hulle uiterlike: hulle kleredrag en hulle versierings. Hy luister ook goed, maar was helaas nie méér as net ' $n$ buitelandse joernalis nie, nié die verlosser waarvoor hy ook aangesien is nie (bl. 30).

Ware mense is vol ironieë en hartseer. Telkens slaan hoop deur, maar nie altyd nie. Al Bart de Graaff se publikasies lees onderhoudend, maar die vennootskap met Danie Hugo as vertaler van hierdie boek uit Nederlands het 'n besondere klank. Dit is verblydend dat Nederlandse entiteite, soos vermeld, as befondsers (deels) betrokke was by die navorsing en die publikasie van hierdie boek.

Met al die name en historiese gegewens wat daarin vervat is, sou 'n indeks baie nuttig gebruik kon word.

Bart de Graaff deel sy eerstehandse waarneming oor SuiderAfrika se ware mense met lesers wat gou agterkom hoe belangrik sy bydrae tot hierdie kennisgebied is. Protea Boekhuis het De Graaff se projek reg aangedoen met 'n besonder keurige uitgawe. 'n Waarskuwing: Moet dié boek nie uitleen nie! Dit is goed moontlik dat dit nie weer teruggegee sal word nie. 